\title{
Stress and breast cancer: from epidemiology to molecular biology
}

\author{
Lilia Antonova ${ }^{1 *}$, Kristan Aronson ${ }^{2}$ and Christopher R Mueller
}

\begin{abstract}
Stress exposure has been proposed to contribute to the etiology of breast cancer. However, the validity of this assertion and the possible mechanisms involved are not well established. Epidemiologic studies differ in their assessment of the relative contribution of stress to breast cancer risk, while physiological studies propose a clear connection but lack the knowledge of intracellular pathways involved. The present review aims to consolidate the findings from different fields of research (including epidemiology, physiology, and molecular biology) in order to present a comprehensive picture of what we know to date about the role of stress in breast cancer development.
\end{abstract}

\section{Introduction}

Studies have estimated that approximately $50 \%$ of breast cancer incidence can be attributed to known genetic, physiologic, or behavioral risk factors [1], with genetic risk factors accounting for 5 to $10 \%$ of breast cancer cases [2]. Established physiological and behavioral risk factors for breast cancer include having a first-degree relative with breast cancer, early menarche, late menopause, nulliparity or bearing of first child at a later age, overweight after menopause, certain types of benign breast diseases, alcohol consumption, and long-term use of menopausal estrogen replacement therapy [3]. In addition to these well-characterized contributors, other factors, whose effects have been more difficult to evaluate, are suspected of conferring increased breast cancer risk. These factors include smoking, certain aspects of nutrition (meat and fat consumption), physical activity, and psychological stress $[4,5]$.

\footnotetext{
*Correspondence: lantonova@ohri.ca
}

'Center for Cancer Therapeutics, Ottawa Hospital Research Institute, 501 Smyth Rd, TOHCC 3rd floor, Ottawa, ON, K1H 8L6, Canada

Full list of author information is available at the end of the article
The possible contribution of psychological stress to breast cancer development has been extensively studied. Literature on the topic is not only abundant, spanning several decades, but is scattered between the fields of epidemiology, physiology, and molecular biology. Whereas the largest amount of literature focuses on using epidemiologic methods to look for a connection between exposure to stress and subsequent breast cancer diagnosis, this portion of the literature is also the most difficult to assess. Studies in this area differ greatly in their findings, probably due to differences in factors such as study design, the effects of confounding, type of stress exposure, and timing of stress exposure or stress exposure measurement. On the other hand, animal literature on the topic is simpler to interpret, for the most part pointing to a connection between physiological stress signaling and breast cancer development. This literature is limited, however, by a lack of variability in stress exposure parameters and the differences in breast physiology and development between mice and humans. Finally, molecular studies demonstrate a clear overlap between intracellular stress signaling and protumorigenic pathways within breast cells, but need to be integrated with other stress-breast cancer research in order to obtain an unambiguous assessment of the potential cause-effect relationship.

In the present review, we provide a comprehensive picture of the current state of knowledge in the stressbreast cancer field. We shall first begin with epidemiology (which looks at the stress-breast cancer association in human populations) as the most directly relevant study of the human condition, will then continue with the physiological rationale behind a stress-breast cancer association, will present physiological research in this field (which examines the direct correlation between experimentally-induced stress and tumor development in animals), and shall end with molecular biology (providing the cellular mechanisms through which stress may contribute to breast cancer development). We will identify the sources of study discrepancy (in the case of epidemiology) or the gaps in knowledge (in the case of physiology and molecular biology) that should be addressed in order to further advance scientific 
understanding, and we shall discuss future research directions that would benefit from a multidisciplinary approach.

\section{Methodology}

English-language article and book sources from MedLine, PubMed, and PsycINFO were employed in the present review. The listed databases were searched for a large number of combinations of terms pertaining to the various fields referenced, but some general search terms included: stress or psychological stress (cross-referenced with terms from all fields, such as cancer, breast cancer, mammary gland, glucocorticoid receptor (GR), hypothalamic-pituitary-adrenal (HPA) axis, animal studies, apoptosis, DNA repair, immunity), cortisol, GR, HPA axis, mammary gland development, life events, animal studies and cancer. No publication date limits were set, but the publication dates for the sources included range between 1973 and 2010.

\section{Epidemiologic evidence for a stress-breast cancer association}

Epidemiologic research on this topic concentrates on testing for an association between exposure to a stressful stimulus and an outcome of breast tumor diagnosis. Historically, this was attempted primarily with the use of retrospective case-control study designs where incident breast cancer cases are usually matched with populationbased or hospital-based controls. Recollection of exposure to stress was recorded through questionnaires and assessed for its association with breast cancer. Interpretation of these studies, however, was complicated by a number of limitations, the most important of which is potential recall bias - subjects are more likely to remember stress exposure if they have been diagnosed with breast cancer.

More recently, a type of prospective study design has been employed in which exposure information is obtained prior to knowledge of breast cancer diagnosis (limited prospective design). In such studies, subjects who have undergone a biopsy for suspected breast disease, but have not yet received a diagnosis, are asked about their previous exposure to stress. Although the goal of this type of study design is to reduce the recall bias associated with case-control studies, it has been observed that in many cases women are able to correctly predict their diagnosis after biopsy [6]. Recall of stressful events may thus still be compromised. Consequently, there has been a recent shift in the field towards the employment of truly prospective designs. These designs aim to determine whether exposure information obtained at the beginning of the study is associated with increased risk of breast cancer determined after a long period of follow-up. Results from some large prospective cohorts have recently become available.
In this section we aim to present an overview of the current state of knowledge by outlining the trends demonstrated by the two main meta-analyses on the topic of stress and breast cancer in the field of epidemiology. In addition, with the help of more recently published findings (Table 1), we aim to identify the factors that need to be taken into consideration in order to definitively establish whether stress plays a role in breast cancer etiology.

A meta-analytical review of epidemiologic studies in the area of stress and breast cancer incidence was carried out by Petticrew and colleagues, with specific testing for an association between bereavement and breast cancer, and other life events (including total number of life events, major life changes, separation, war experiences, serious illness, financial problems, and work problems) and breast cancer [7]. Owing to the scope of the literature at the time, the analysis was limited to case-control and limited prospective designs: 11 studies for bereavement and breast cancer (six case-control studies and five limited prospective studies); 15 studies for other life events and breast cancer (eight case-control studies and seven limited prospective studies). The studies spanned the time period between 1966 and 1997. This metaanalysis demonstrated no association between bereavement and breast cancer (odds ratio $(\mathrm{OR})=1.06,95 \%$ confidence interval $(\mathrm{CI})=0.95$ to 1.18 ), but a more than twofold increase in breast cancer risk was associated with other life events $(\mathrm{OR}=2.63,95 \% \mathrm{CI}=2.34$ to 2.96$)$. Limiting the analysis to only the highest quality studies (five for other life events) resulted in no apparent association $(\mathrm{OR}=0.8,95 \% \mathrm{CI}=0.61$ to 1.06$)$.

A more recent meta-analysis was performed by Duijts and colleagues [8]. Twenty-seven studies published between 1966 and December 2002 examining the relationship between stressful life events and breast cancer risk were analyzed. The studies encompassed a wider variety of research designs and included ten retrospective case-control studies, four prospective casecontrol studies, nine limited prospective cohort studies, and four prospective cohort studies. The findings concluded that variables significantly associated with breast cancer risk are an increased number of stressful life events $(\mathrm{OR}=1.77,95 \% \mathrm{CI}=1.31$ to 2.40$)$, death of a significant other $(\mathrm{OR}=1.37,95 \% \mathrm{CI}=1.10$ to 1.71$)$, and death of a relative or friend $(\mathrm{OR}=1.35,95 \% \mathrm{CI}=1.09$ to 1.68). Interestingly, a disparity in results was found on the basis of study design. Prospective studies showed a higher summary OR associated with stressful life events than retrospective design studies $(\mathrm{OR}=2.46,95 \% \mathrm{CI}=$ 0.98 to 6.18 and $\mathrm{OR}=1.93,95 \% \mathrm{CI}=1.13$ to 3.31 , respectively). This was attributed to the possible presence of recall bias in retrospective studies. In addition, studies that took into account well-established breast cancer risk 
Table 1. Prospective epidemiologic studies looking at the effect of stress on breast cancer risk

\begin{tabular}{|c|c|c|c|c|c|c|}
\hline Study & Study design & Sample size & Follow-up & $\begin{array}{l}\text { Stress-exposure } \\
\text { measure }\end{array}$ & $\begin{array}{l}\text { Control for } \\
\text { confounding }\end{array}$ & Results \\
\hline $\begin{array}{l}\text { Kuper and } \\
\text { colleagues [15] }\end{array}$ & $\begin{array}{l}\text { Prospective } \\
\text { cohort }\end{array}$ & 36,332 & 13 years & $\begin{array}{l}\text { Work-related } \\
\text { stressors }\end{array}$ & Yes & $\begin{array}{l}\text { Association found for low job control and high job } \\
\text { demands ( } H R=1.3 \text { (1.0 to } 1.7) \text { for both), and job strain } \\
(H R=1.4(1.1 \text { to } 1.9))\end{array}$ \\
\hline $\begin{array}{l}\text { Nielsen and } \\
\text { colleagues [16] }\end{array}$ & $\begin{array}{l}\text { Prospective } \\
\text { cohort }\end{array}$ & 18,932 & 10 years & $\begin{array}{l}\text { Work-related } \\
\text { stressors }\end{array}$ & Yes & $\begin{array}{l}\text { No association found for high work pressure, } \\
\text { influence on job organization, and long working } \\
\text { hours; association but no dose-response effect found } \\
\text { for high work tempo (HR } 1.25 \text { (1.02 to 1.54)) }\end{array}$ \\
\hline $\begin{array}{l}\text { Schernhammer } \\
\text { and colleagues } \\
{[17]}\end{array}$ & $\begin{array}{l}\text { Prospective } \\
\text { cohort }\end{array}$ & 37,562 & 8 years & $\begin{array}{l}\text { Work-related } \\
\text { stressors }\end{array}$ & Yes & $\begin{array}{l}\text { No association found for women in passive }(R R=0.90 \\
(0.76 \text { to } 1.06)) \text {, active }(R R=0.83(0.69 \text { to } 0.99)) \text { or } \\
\text { high-strain jobs ( } R R=0.87(0.73 \text { to } 1.04))\end{array}$ \\
\hline $\begin{array}{l}\text { Kroenke and } \\
\text { colleagues [18] }\end{array}$ & $\begin{array}{l}\text { Prospective } \\
\text { cohort }\end{array}$ & 32,826 & 8 years & Caregiving stress & Yes & $\begin{array}{l}\text { No association found for adult care }(\mathrm{RR}=1.19(0.87 \text { to } \\
1.62)) \text { or child care }(\mathrm{RR}=0.87(0.66 \text { to } 1.16))\end{array}$ \\
\hline $\begin{array}{l}\text { Nielsen and } \\
\text { colleagues [19] }\end{array}$ & $\begin{array}{l}\text { Prospective } \\
\text { cohort }\end{array}$ & 7,018 & $\begin{array}{l}16 \text { to } \\
18 \text { years }\end{array}$ & $\begin{array}{l}\text { Total stress at } \\
\text { baseline }\end{array}$ & Yes & $\begin{array}{l}\text { Lower risk associated with high stress at baseline } \\
(H R=0.60(0.37 \text { to } 0.97))\end{array}$ \\
\hline $\begin{array}{l}\text { Surtees and } \\
\text { colleagues [20] }\end{array}$ & $\begin{array}{l}\text { Prospective } \\
\text { cohort }\end{array}$ & 11,467 & $\begin{array}{l}\text { Median } \\
9 \text { years }\end{array}$ & $\begin{array}{l}\text { Difficulties in } \\
\text { childhood, self- } \\
\text { perceived stress }\end{array}$ & Yes & $\begin{array}{l}\text { No association found for difficulties in childhood } \\
(H R=1.02(0.91 \text { to } 1.16)) \text {, life events within } 5 \text { years } \\
\text { previous to study }(H R=0.99(0.89 \text { to } 1.11)) \text {, or } \\
\text { perceived stress within } 10 \text { years previous to study } \\
(H R=1.17(0.84 \text { to } 1.64))\end{array}$ \\
\hline $\begin{array}{l}\text { Metcalfe and } \\
\text { colleagues [21] }\end{array}$ & $\begin{array}{l}\text { Prospective } \\
\text { cohort }\end{array}$ & 991 & 30 years & Daily stress & Yes & $\begin{array}{l}\text { Mild correlation for moderate }(H R=2.16(1.00 \text { to } 4.71)) \\
\text { and high }(H R=1.92(0.81 \text { to } 4.55)) \text { daily stress }\end{array}$ \\
\hline $\begin{array}{l}\text { Helgesson and } \\
\text { colleagues [11] }\end{array}$ & $\begin{array}{l}\text { Prospective } \\
\text { cohort }\end{array}$ & 1,462 & 24 years & Self-perceived stress & Yes & $\begin{array}{l}\text { Association found for self-reported stress during the } \\
5 \text { years prior to baseline }(R R=2.1(1.2 \text { to } 3.7))\end{array}$ \\
\hline $\begin{array}{l}\text { Lillberg and } \\
\text { colleagues [22] }\end{array}$ & $\begin{array}{l}\text { Prospective } \\
\text { cohort }\end{array}$ & 10,808 & 14 years & Life events & Yes & $\begin{array}{l}\text { Associations found for major life events }(H R=1.35 \\
\text { (1.09 to } 1.67)) \text {, divorce/separation }(H R=2.26(1.25 \text { to } \\
4.07)) \text {, death of a husband ( } H R=2.00(1.03 \text { to } 3.88)) \text {, } \\
\text { or death of a close relative or friend ( } H R=1.36(1.00 \\
\text { to } 1.86))\end{array}$ \\
\hline $\begin{array}{l}\text { Lambe and } \\
\text { colleagues [23] }\end{array}$ & Registry study & $\begin{array}{l}27,571 \text { cases, } \\
141,798 \\
\text { controls }\end{array}$ & & Loss of a child & Yes & $\begin{array}{l}\text { Association found for loss of a child between the ages } \\
\text { of } 1 \text { and } 4(\mathrm{OR}=2.65 \text { (1.06 to } 6.60))\end{array}$ \\
\hline $\begin{array}{l}\text { Ollonen and } \\
\text { colleagues [24] }\end{array}$ & $\begin{array}{l}\text { Limited } \\
\text { prospective }\end{array}$ & $\begin{array}{c}34 \text { cases, } \\
81 \text { controls } \\
\text { (53 with } \\
\text { benign breast } \\
\text { disease, } \\
28 \text { no disease) }\end{array}$ & & Life events & Yes & $\begin{array}{l}\text { Association found for very severe and severe losses } \\
(P=0.02) \text { and greater number of moderate or severe } \\
\text { losses }(P=0.0009)\end{array}$ \\
\hline $\begin{array}{l}\text { Michael and } \\
\text { colleagues [10] }\end{array}$ & $\begin{array}{l}\text { Prospective } \\
\text { cohort }\end{array}$ & 84,334 & $\sim 8$ years & Life events & Yes & $\begin{array}{l}\text { Association found for one life event ( } H R=1.12 \text { ( } 1.0 \text { to } \\
1.25) \text { ), no dose-response }\end{array}$ \\
\hline $\begin{array}{l}\text { Eskelinen and } \\
\text { Ollonen [28] }\end{array}$ & $\begin{array}{l}\text { Limited } \\
\text { prospective }\end{array}$ & $\begin{array}{l}34 \text { cases, } 81 \\
\text { controls (53 } \\
\text { with benign } \\
\text { breast disease, } \\
28 \text { no disease) }\end{array}$ & & $\begin{array}{l}\text { Losses and deficit in } \\
\text { childhood }\end{array}$ & Yes & $\begin{array}{l}\text { Association found for deficit in childhood }(P<0.05) \text { or } \\
\text { severe deficit in childhood }(P=0.02)\end{array}$ \\
\hline $\begin{array}{l}\text { Jacobs and } \\
\text { Bovasso [29] }\end{array}$ & $\begin{array}{l}\text { Prospective } \\
\text { cohort }\end{array}$ & 1,213 & $\sim 15$ years & Life events & Yes & $\begin{array}{l}\text { Association found for maternal death in childhood } \\
(\mathrm{OR}=2.56(1.59 \text { to } 4.35))\end{array}$ \\
\hline $\begin{array}{l}\text { Keinan-Boker } \\
\text { and colleagues } \\
\text { [30] }\end{array}$ & Registry study & $\begin{array}{c}37,872 \\
\text { women }\end{array}$ & $\begin{array}{l}\text { 2,670,238 } \\
\text { person-years } \\
\text { for women }\end{array}$ & Holocaust exposure & No & $\begin{array}{l}\text { Association found for Holocaust exposure }(R R=2.44 \\
\text { (1.46 to 4.06) for youngest birth cohort; lower but } \\
\text { significant association for other birth cohorts) }\end{array}$ \\
\hline $\begin{array}{l}\text { Koupil and } \\
\text { colleagues [31] }\end{array}$ & $\begin{array}{l}\text { Prospective } \\
\text { cohort }\end{array}$ & $\begin{array}{c}1,429 \\
\text { women }\end{array}$ & $\begin{array}{l}\text { Not } \\
\text { estimated }\end{array}$ & $\begin{array}{l}\text { Leningrad siege } \\
\text { exposure }\end{array}$ & Some & $\begin{array}{l}\text { Association found for Leningrad siege exposure and } \\
\text { breast cancer mortality in women } 10 \text { to } 18 \text { years old } \\
\text { at time of exposure (HR }=9.9(1.1 \text { to } 86.5))\end{array}$ \\
\hline
\end{tabular}


factors showed a statistically significant association with stress (for example, $\mathrm{OR}=2.22,95 \% \mathrm{CI}=1.39$ to 3.56 for stressful life events), whereas studies that did not control for such factors did not report an association when pooled (for example, $\mathrm{OR}=1.04,95 \% \mathrm{CI}=0.90$ to 1.20 for stressful life events).

The differences between the above-described metaanalytical results reflect the wide diversity in findings between studies. They also, however, highlight the factors that may be sources of discrepancies and that need to be addressed in future research in order to move this research field forward. These factors and some other possible causes of discordance are the type of study design, control for confounding, the timing of stress exposure, and the type of stress exposure. Further support for the importance of consideration of these factors in study design or analysis is lent by investigations published following the release of the discussed metaanalytical reviews.

\section{Study design and control for confounding}

The influence of study design and control for confounding on results is quantitatively demonstrated by the differences in ORs observed in the analysis by Duijts and colleagues for retrospective studies and prospective studies and for studies accounting for confounding versus those that do not [8]. Study design and confounding probably contributed to the difference in results between the two meta-analyses presented. At the time of the earlier analysis, fewer prospective studies had been published. In addition, the majority of earlier research does not account for the effect of confounding factors. Several factors - such as diet, exercise, and hormone exposure - are associated with both the exposure (stress) and the outcome (breast cancer) of interest, and therefore need to be considered in this context as potential confounders [8-10].

Another important variable to take into account is the effect of socioeconomic status on the association of stress with breast cancer risk. At this point in time, it is unclear whether stress acts as a mediating factor between socioeconomic status and breast cancer, or whether socioeconomic status and stress are independently correlated with breast cancer risk. Evidence has been presented for both possibilities [11,12]. The analysis of stress-breast cancer associations should therefore be carried out in both the presence of and the absence of socioeconomic status in order to rule out a confounding effect.

\section{Type of stress}

Stress can be acute (short-lived) or chronic (repetitive or occurring over an extended period of time) [13,14]. There appears to be a tendency towards stronger associations being observed in studies looking at certain types of stressful life events and breast cancer incidence, compared with those studies examining chronic stress such as work-related stress, caregiving stress, or everyday/total stress.

The effect of work-related stress on breast cancer risk was assessed in some recent prospective cohort studies. In a study by Kuper and colleagues, the effect of job strain on breast cancer incidence was examined among 36,332 Swedish women participating in the Women's Lifestyle and Health Cohort Study, followed for an average of 13 years [15]. The results showed that both low job control and high job demands were associated with breast cancer risk among women working full-time, whereas an even stronger association was observed among women exposed to both of these variables (Table 1). These results were contradicted, however, by results from nurse cohort studies. In a prospective cohort study in which 18,932 women in the Danish Nurse Cohort were assessed for the effect of work-related stressors on breast cancer [16], high work pressure, influence on job organization and long working hours were not associated with breast cancer risk. High work tempo/speed showed an association with increased risk but no dose-response effect. Similarly, the Nurses' Health Study showed no association between high-strain jobs and breast cancer risk [17]. Since the above studies employ a similar design, the disparity in findings regarding work stress suggests that the relationship of this type of stress to breast cancer is difficult to assess accurately, and may be affected by the specific measurement method of work stress or by some of the other sources of study discrepancy discussed.

Caregiving stress was examined in the Nurses' Health Study in a cohort of 32,826 women followed for 8 years. No association between caregiving stress and breast cancer was observed [18].

The existence of a relationship between everyday/total stress and breast cancer risk has also proven difficult to establish. Participants in the Copenhagen City Heart Study who had reported high levels of stress at baseline were found to have a lower risk of developing breast cancer [19]. A study examining lifetime social adversity within 11,467 women in the European Prospective Investigation into Cancer - Norfolk cohort found no association for specific measures of social adversity, such as difficulties reported in childhood, and perceived stress within the previous 10 years [20]. These results are opposed by the findings that moderate and high daily stress showed a mild correlation with higher breast cancer risk in the West of Scotland Collaborative Study [21], and that self-reported stress in the 5 years preceding the study baseline is associated with breast cancer risk [11].

In contrast to the above stress categories, stress induced by life events shows a more consistent association with breast cancer risk in prospective studies. For 
example, a life event-breast cancer association was observed in the Finnish Twin Cohort prospective study [22]. An association for life events with breast cancer risk was also observed in a recent registry study [23], in a limited prospective design study [24], and in the Women's Health Initiative cohort study [10]. The European Prospective Investigation into Cancer - Norfolk study, however, found no association for life events within the 5 years previous to study baseline [20], demonstrating that factors other than the type of stress also contribute to study discrepancy.

\section{Timing of stress exposure}

Variability between studies may also stem from the distinctive time windows of relevant exposure to stress examined. The latency period between stress exposure and breast cancer initiation is unknown. In general, the process of breast cancer development is estimated to occur over 10 to 20 years [25,26]. In agreement with this, a study by Lillberg and colleagues found that breast cancer risk is most strongly correlated with life events that have occurred within 11 years prior to diagnosis [27]. Since the time periods of exposure examined in different studies vary widely, some of the assessed exposures may fall outside the biologically relevant time, thus leading to different study results.

Another time-associated factor that needs to be taken into consideration is the possibility that exposure to stress at certain periods of development may have a stronger impact on breast physiology. Women diagnosed with breast cancer were found to be significantly more likely to have undergone stress due to losses or social deficits in childhood and adolescence, for example [28]. Similarly, death of a mother during a girl's childhood was found to be significantly associated with increased breast cancer risk in a prospective cohort in the Baltimore Epidemiologic Catchment Area Study [29]. Finally, in a registry study and a prospective cohort study looking at association of stress caused by exposure to the Holocaust or to the siege of Leningrad with breast cancer risk or mortality, respectively, stress among women younger than 18 years old was found to be associated with the highest risk and mortality of breast cancer (although the association in the Leningrad study did not reach statistical significance) [30,31]. These studies also suggest that the cancer-causing effects of stress may be fairly specific to the breast. In both cases, all types of cancer were examined, and breast cancer showed the strongest association with stress.

\section{Conclusions from the epidemiologic literature}

Epidemiologic evidence in the area of stress and breast cancer outlines several trends. Firstly, the effect of stress appears to be relatively breast specific, possibly due to the biological roles of stress signaling in the mammary gland (described in the next section).

Secondly, the type of stress examined affects the study results in this area. The stress most strongly associated with increased breast cancer risk appears to be stress induced by major life events, whereas findings regarding work-related, caregiving, or everyday stress vary considerably. The dependence of results on the stress type may stem from variable biological effects associated with different types of stress, an area that needs to be further investigated with the help of physiological methods.

The timing of stress exposure also has an effect on breast cancer risk, with early life stress exhibiting the strongest association with breast cancer.

Finally, a greater number of prospective studies is necessary for each subcategory of stress or timing of stress exposure in order to more definitively understand the stress-breast cancer relationship.

\section{Biological plausibility of a stress-breast cancer association}

The plausibility of a stress-breast cancer association stems from two important physiological roles of the stress hormone cortisol. Cortisol plays an essential part in mammary gland development and function, which may sensitize mammary tissues to modulations in cortisol signaling in the presence of stress. It also has an impact on certain aspects of estrogen activity in the mammary gland, which may initiate protumorigenic changes during periods of stress.

\section{The physiological stress response}

Stress is defined as 'an alteration in the body's hormonal and neuronal secretions caused by the central nervous system in response to a perceived threat' [32,33]. The long-term response to psychosocial stressors in humans consists of activating the HPA axis of hormonal signaling [34]. Corticotropin-releasing hormone produced in the hypothalamus stimulates the release of adrenocorticotropic hormone from the anterior pituitary. Adrenocorticotropin, in turn, signals the adrenal cortex to produce the 'stress hormone', cortisol. Cortisol generates a physical response to the stress signal by binding to its cytoplasmic receptor, GR, and promoting protein, lipid, and carbohydrate catabolism [35,36].

In its ordinary physiological role, cortisol has protective effects on the organism by regulating immune function, promoting memory of dangerous events, increasing blood pressure and heart rate to meet the physical demands of a fight or flight response, and making fuel available for sustaining increased physical activity [37]. Prolonged stress-response conditions similar to those stimulated by stressful life events, however, have been shown to predispose for illnesses such as hypertension, 
atherosclerosis, osteoporosis, immune dysfunction, and cancer in laboratory studies [37-39]. Breast cancer development has been proposed to be correlated with such prolonged stress exposure [39]. As pointed out above, this may be a function of the natural role of cortisol in the development and activity of the mammary gland.

\section{Role of stress signaling pathways in the mammary gland}

The mammary gland begins to form early during embryogenesis and continues to develop in defined stages that are correlated with sexual development and reproduction [40-42]. Laboratory studies have demonstrated that cortisol plays a physiological role in the mammary gland mainly in the latter part of pregnancy and during lactation (Figure 1). At that stage, placental lactogens stimulate DNA synthesis in the mammary cells, and cortisol induces the formation of the rough endoplasmic reticulum, where milk proteins will be synthesized [42]. Prolactin release upon birth causes lobular differentiation, and the secretion of early milk proteins such as $\beta$ casein. Cortisol, on the other hand, predominantly regulates the expression of late milk proteins, although it has also been shown to play an important role in the regulation of $\beta$-casein expression [43].

These breast-specific functions of cortisol signaling have been confirmed by studies in mice defective for the intracellular mediator of cortisol, the GR. These studies have demonstrated that GR activity is involved in the ductal development of the virgin mammary gland [44], in lobuloalveolar mammary gland development during pregnancy (via the induction of proliferation) [45], and in stimulating milk production during lactation. Owing to the natural functions of cortisol in regulating mammary gland biology, its misregulation and prolonged presence during periods of stress is likely to expose breast cells to the activation of downstream biological pathways outside their normal context. Studies indicate that stressful life events, as well as job stress, produce elevated cortisol levels years after the exposure [46-48]. This elevation would significantly prolong the effect of cortisol on the mammary gland. In addition, stress causes permanent changes in HPA-axis responsiveness [49,50], which may compromise the body's ability to buffer any negative effects of subsequent stress exposure.

In concordance with directly affecting the molecular signaling pathways of mammary cells, cortisol may indirectly contribute to breast tumorigenesis by altering the generation or activity of estrogen. A large body of evidence suggests that estrogen plays a key role in breast cancer etiology [51,52]. One important source of estrogen in the breast is the conversion of adrogens to estrone in stromal cells by the enzyme aromatase [53,54]. Research has shown that aromatase activity [55] and mRNA levels [56] are increased in stromal areas surrounding mammary tumors and that aromatase is able to stimulate the proliferation of breast cancer cells in vitro [57]. Cortisol has been characterized as an inducer of aromatase activity when in the presence of serum [58] or plateletderived growth factor [59]. Treatment of stromal breast cells with the glucocorticoid inhibitor RU486 results in loss of aromatase activation by the aromatase inducer dibutyryl-cAMP [60], demonstrating a necessity for cortisol participation in this process. Stimulation of breast cancer development by prolonged or elevated presence of cortisol during periods of stress may therefore partially occur as a result of augmented estrogen production.

Research in our laboratory has also demonstrated a functional interaction between cortisol and estrogen signaling. We had previously found that cortisol treatment results in downregulation of expression of the gene encoding the tumor-suppressor breast cancer susceptibility gene 1 (BRCA1). The BRCA1 promoter is known to contain an estrogen receptor response element and to be activated by estrogen activity [61]. Since BRCA1 is capable of blocking estrogen-initiated cell proliferation and estrogen signaling pathways [62], the upregulation of $B R C A 1$ expression by estrogen is thought to represent a feedback mechanism by which rapidly proliferating cells control their growth [61]. Factors that obstruct this mechanism are expected to produce unchecked cell proliferation. We have determined that cortisol may act as one such factor. Cortisol treatment of breast cells resulted in loss of estrogen-induced stimulation of BRCA1 expression [63].

The above-described functions of cortisol may contribute to breast cancer development in response to stress. Their effect, however, may be dependent on individual genetic stress susceptibility. Specific polymorphisms in the GR gene have been shown to play a role in an individual's response to stress. For example, increased GR responsiveness to glucocorticoid signaling has been indicated for an aspartic acid to serine change in codon 363 of the GR (N363S), found in 3 to $7 \%$ of Caucasians [64]. This heightened sensitivity to stress has been correlated with a number of cortisol-specific metabolic changes [64-68], and is likely to amplify the effect of cortisol signaling on the mammary gland. Importantly, such a genetic predisposition to stress-induced breast cancer development is supported by the observation that a highly polymorphic dinucleotide CA repeat (D5S207), suspected to occur in linkage disequilibrium with a polymorphism within the GR locus, is associated with an increase in breast cancer risk [69].

\section{Physiological studies on stress and breast tumor growth}

As discussed in the previous section, multiple variables may impact the magnitude or measurement of an 


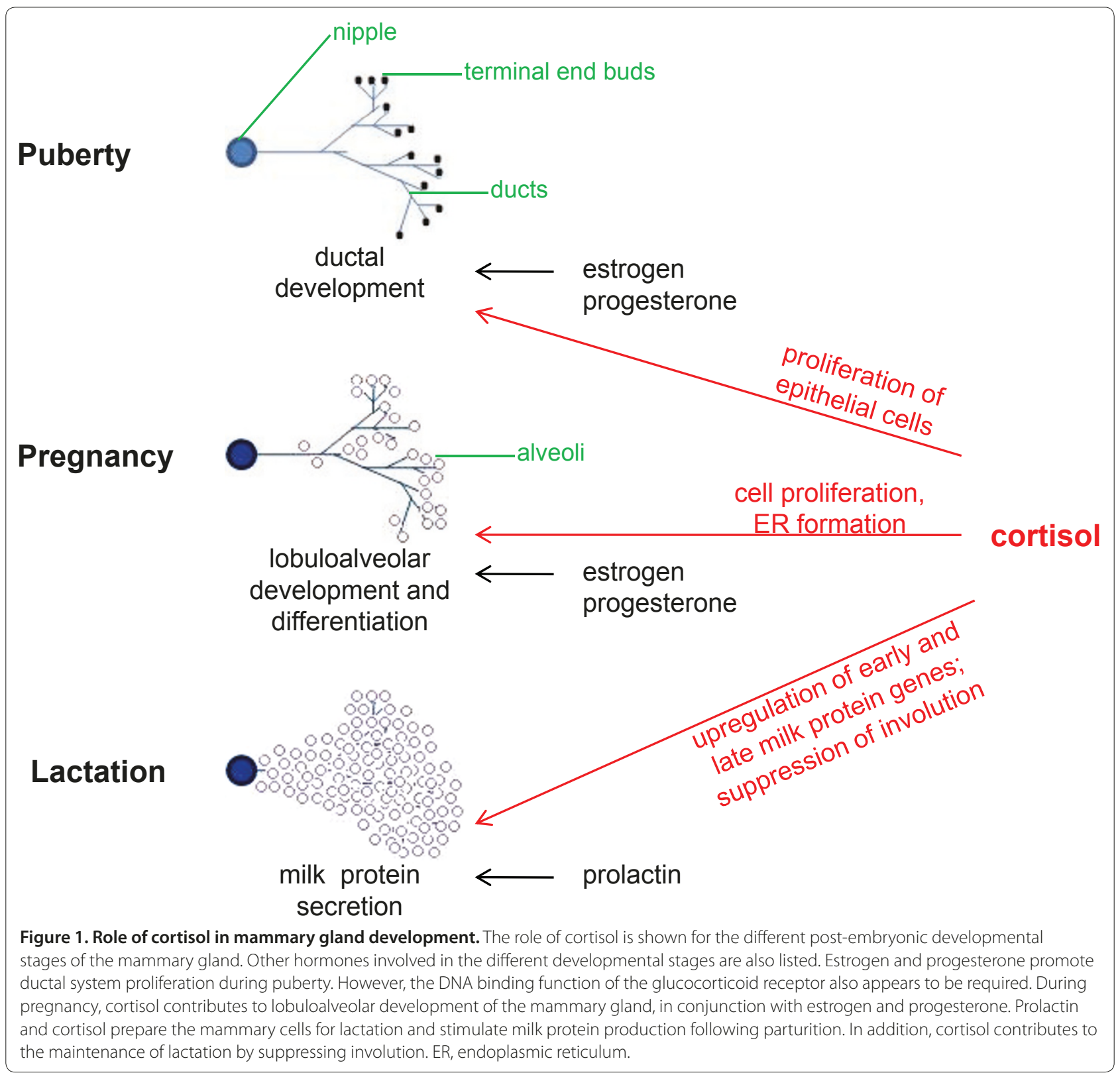

association between exposure to a stressful stimulus and breast cancer development. This complexity makes an unequivocal relationship between stress and breast cancer difficult to demonstrate using epidemiologic methods. Laboratory investigations can therefore complement epidemiologic findings by allowing for a measurement of the impact of stress exposure on mammary gland physiology in a controlled environment. Such studies (summarized in Table 2) have been carried out in animals by employing the method of stress induction via social isolation. Social isolation and a change in social environment are methods previously correlated to an increase in the release of adrenocorticotropic hormone and corticosterone [70], and to enhanced tumor size [71,72]. The use of these techniques by the studies outlined below has allowed for the establishment of a contributing effect of stress on breast tumor growth and incidence.

In a study using male mice transplanted with an androgen-responsive mammary tumor, Weinberg and Emerman showed that socially isolated animals, additionally exposed to acute daily novelty stress (changes in housing conditions), exhibit a marked increase in tumor growth as compared with group-housed animals [73]. These results were confirmed in a follow-up study, in which mammary-tumor-transplanted mice switched from group housing to individual housing were found to have faster tumor growth rates as compared with mice switched from individual housing to group housing [74]. 
Table 2. Physiological studies looking at the effect of stress on DNA damage and tumor development

\begin{tabular}{|c|c|c|c|c|}
\hline Study & Study focus & Study design & Subjects & Results \\
\hline $\begin{array}{l}\text { Kiecolt-Glaser and } \\
\text { colleagues [104] }\end{array}$ & DNA damage & $\begin{array}{l}\text { DNA-repair capacity in } \\
\text { lymphocytes in response to } \\
\text { X-ray irradiation }\end{array}$ & $\begin{array}{l}\text { Distressed vs. nondistressed } \\
\text { psychiatric patients }\end{array}$ & $\begin{array}{l}\text { Lower DNA repair capacity in } \\
\text { distressed individuals }\end{array}$ \\
\hline $\begin{array}{l}\text { Glaser and } \\
\text { colleagues [105] }\end{array}$ & DNA damage & $\begin{array}{l}\text { DNA repair capacity during } \\
\text { period of stress }\end{array}$ & $\begin{array}{l}\text { Medical students during } \\
\text { examination }\end{array}$ & $\begin{array}{l}\text { Increase in DNA repair capacity } \\
\text { during period of stress, possibly } \\
\text { as initial response to increased } \\
\text { DNA damage }\end{array}$ \\
\hline $\begin{array}{l}\text { Cohen and } \\
\text { colleagues [106] }\end{array}$ & DNA damage & $\begin{array}{l}\text { Levels of O6-methylguanine- } \\
\text { methyltransferase following } \\
\text { stress exposure }\end{array}$ & Stressed vs. control rats & $\begin{array}{l}\text { Levels of DNA repair enzyme } \\
\text { are reduced in stressed rats }\end{array}$ \\
\hline $\begin{array}{l}\text { Fischman and } \\
\text { colleagues [107] }\end{array}$ & DNA damage & $\begin{array}{l}\text { Rate of sister chromatid exchanges } \\
\text { in response to } \gamma \text {-irradiation, } \\
\text { mitomycin- } C \text { in the presence of } \\
\text { environmental stressors }\end{array}$ & Stressed vs. control rats & $\begin{array}{l}\text { Increase in sister chromatid } \\
\text { exchanges in stressed rats; } \\
\text { increased susceptibility to } \\
\text { mutagenesis }\end{array}$ \\
\hline $\begin{array}{l}\text { Adachi and } \\
\text { colleagues [109] }\end{array}$ & DNA damage & $\begin{array}{l}\text { Rate of DNA mutation occurrence } \\
\text { Oxidative damage }\end{array}$ & Stressed vs. control rats & $\begin{array}{l}\text { Increased rate of DNA mutation } \\
\text { occurrence in stressed rats }\end{array}$ \\
\hline $\begin{array}{l}\text { Weinberg and } \\
\text { Emerman [73] }\end{array}$ & Tumor development & $\begin{array}{l}\text { Tumor growth in response to } \\
\text { acute daily novelty stress }\end{array}$ & $\begin{array}{l}\text { Socially isolated vs. group- } \\
\text { housed male mice }\end{array}$ & $\begin{array}{l}\text { Increased tumor growth in } \\
\text { socially isolated animals }\end{array}$ \\
\hline $\begin{array}{l}\text { Grimm and } \\
\text { colleagues [74] }\end{array}$ & Tumor development & $\begin{array}{l}\text { Tumor growth in response to change } \\
\text { in housing conditions }\end{array}$ & $\begin{array}{l}\text { Mice switched from group to } \\
\text { individual housing vs. individual } \\
\text { to group housing }\end{array}$ & $\begin{array}{l}\text { Increased tumor growth rate in } \\
\text { mice switched from group to } \\
\text { individual housing }\end{array}$ \\
\hline $\begin{array}{l}\text { Hermes and } \\
\text { colleagues [75] }\end{array}$ & Tumor development & $\begin{array}{l}\text { Life-time risk of mammary tumor } \\
\text { incidence, tumor growth rate in } \\
\text { response to social isolation }\end{array}$ & $\begin{array}{l}\text { Socially isolated vs. group- } \\
\text { housed female rats }\end{array}$ & $\begin{array}{l}\text { Increased risk for developing at } \\
\text { least one malignant tumor; } \\
\text { increased tumor growth; } \\
\text { hyperactive response to future } \\
\text { stressors; sustained changes in } \\
\text { HPA-axis signaling }\end{array}$ \\
\hline
\end{tabular}

HPA, hypothalamic-pituitary-adrenal.

In addition to tumor growth, social isolation was shown by Hermes and colleagues to have an effect on lifetime risk of mammary tumor incidence [75]. Socially isolated female Norway rats followed for spontaneous mammary tumor development were found to exhibit a relative risk of 3.3 for developing at least one malignant tumor as compared with group-housed animals, although there was no significant difference in the risk of developing a palpable tumor mass in general. The tumor burden in isolated rats was also 84 times higher. Similar characteristics of tumor development were observed in work by Williams and colleagues in socially isolated mice [76]. The study demonstrated that tumor incidence and tumor size are both increased in isolated mice when compared with group-housed controls, and that this is correlated with a higher number of poorly differentiated adenocarcinomas.

Interestingly, animals exposed to social isolation early in life in the study by Hermes and colleagues showed a hyperactive response to psychological stressors later in life (this was also observed by Williams and colleagues), as well as sustained changes in HPA-axis signaling [75]. Hyperactivity of the stress response was, in turn, correlated with increased tumor burden. It is tempting to speculate that this model presents a situation analogous to the effect of stressful life events on the risk of developing breast cancer later in life. In fact, human studies indicate that HPA-axis signaling in response to a stressor is permanently altered following adverse life events, such as childhood abuse (although the direction 
of change differs between studies) [49,50,77], and that basal cortisol levels may be affected by early and late life events $[78,79]$.

One mechanism for these long-term HPA-axis signaling changes has been revealed through recent investigations employing lack of grooming as a stressor. In these studies, rat pups prevented from being groomed exhibited a heightened stress response when exposed to stressors as adults $[80,81]$. This augmented response was associated with methylation of a far-upstream element in the promoter of the GR gene in cells of the hippocampus, subsequent low levels of GR gene expression, and longterm alteration of HPA-axis signaling due to reduced sensitivity to negative feedback control by glucocorticoids $[82,83]$.

In addition to its effects on GR expression, social isolation was demonstrated to result in global changes in gene expression, and to cause the activation of certain glycolytic and lipogenic metabolic pathways previously correlated with tumor development [76]. These findings provide some of the possible pathways affected by stress, linking physiological and molecular literature on the topic of stress and breast cancer.

\section{Future directions in physiological research}

The animal studies discussed above for the most part demonstrate a connection between stress exposure and breast tumor incidence and growth, corroborating the findings of a subset of the epidemiologic literature. This field suffers from a limited number of studies, however, and needs to be expanded into research directions that would strengthen its applicability to human biology. The most important step forward would be to extend the use of physiological measures of stress to human studies. Although, a retrospective epidemiologic design does not allow for a measurement of stress signaling parameters at the time of stress exposure, certain prospective designs may allow for incorporation of physiological stressmeasurement techniques. For example, physiological measures can be employed in prospective studies of longterm stress (such as work strain or caregiving) where the exposure is ongoing at the time of study initiation, or to test for increased cortisol levels in the presence of a history of life events. Validated methods for stress quantification that can be applied include the measurement of morning and evening salivary or blood cortisol levels $[46,84]$. The detection of anti-Epstein-Barr virus antibodies in the blood has also been implicated as an indirect biological marker of stress $[85,86]$.

An important parallel that emerges between animal and human physiology is the specific role of early life stress on breast cancer development. Epidemiologic studies, however, demonstrate that in addition to the timing of stress exposure, the stress-breast cancer association depends on the type of stress. A limitation of the physiological literature is therefore the lack of variability in stress measures. The primary type of stress employed in animal studies when studying tumor development is social isolation. This type of stress has been proposed to be representative of chronic stress exposures in humans [87]. The correlation between species-specific stress signaling responses, however, requires validation. Social stress has also been shown to affect the development of the mammary gland during puberty, and may therefore not be appropriate for usage in the study of early life events [88]. In addition, there is a need for animal studies representative of other human stressors, such as life events. These studies would allow for the draw of more direct parallels between animal and human findings.

\section{Molecular studies}

The contribution of molecular biology to the stressbreast cancer field of research is twofold. Firstly, molecular biology contributes to the understanding of stress by allowing the elucidation of the intracellular molecular changes which occur in response to stress signaling. Secondly, by examining whether stress impacts tumorigenic pathways within the mammary gland, molecular biology tests the biological plausibility of the stress-breast cancer association observed in some of the epidemiologic literature. Molecular evidence currently points to apoptosis modulation [89], regulation of immune function, and changes in DNA repair mechanisms as the main biological mechanisms through which stress contributes to cancer development.

\section{Stress and apoptosis in the mammary gland}

Consistent with its role in stimulating lactation, cortisol has been shown to suppress apoptosis and involution in the mammary gland [90] and to stimulate prosurvival pathways in nonmalignant mammary epithelial cells in vitro [91]. These observations indicate that prolonged exposure to stress may facilitate tumor progression by suppressing the removal of genetically altered cells. In accordance with these genetic instability-inducing effects, glucocorticoids have been found to inhibit chemotherapy-induced apoptosis [92] and to stimulate invasiveness [93] and adhesion [94] of human breast tumor cells. Furthermore, the GR was found to be overexpressed in $94.4 \%$ of metaplastic carcinomas and in 92.3\% of malignant phyllode tumors [95], implying a link between increased intracellular stress signaling and the development of those types of breast malignancies. Interestingly, some studies have pointed to an inhibition of the growth of certain mammary tumor cell lines in the presence of cortisol $[96,97]$, which may indicate tumortype specificity of the cortisol effect. 
Few breast tissue-specific molecular mechanisms have been proposed for the antiapoptotic effect of stress signaling in such cells. The GR, however, has been shown to be involved in several apoptosis-related pathways in general, which have been reviewed previously [98,99]. In the mammary gland in particular, glucocorticoids have been found to induce both the mRNA levels of the activator protein-1 family members c-fos, jun B, and jun $\mathrm{D}$, and activator protein-1 DNA binding activity [90]. This induction, in turn, leads to the inhibition of activator protein-1 target genes and the suppression of apoptosis and of mammary gland involution. In malignant mammary cells, the synthetic glucocorticoid dexamethasone has been found to repress mitogen-activated protein kinase-induced apoptosis by upregulating the expression of mitogen-activated protein kinase phosphatase-1 [92]. The GR has also been shown to signal through the serum and glucocorticoid-regulated kinase-1 to decrease the proapoptotic activity of Forkhead transcription factor 3a in the breast cancer cell line SKBR-3 [100]. Finally, the synthetic glucocorticoid dexamethasone has been found to inhibit TNF $\alpha$-induced apoptosis by suppressing the degradation of several inhibitors of apoptosis proteins, including cIAP1, cIAP2, and XIAP [101].

\section{Stress and immune detection of transformed cells}

Stress may also contribute to mammary tumor development by affecting immune system function and the elimination of transformed mammary cells. The effect of stress signaling on immunity has been extensively studied and was recently reviewed by Webster Marketon and Glaser [102]. With respect to cancer development, cortisol release in response to psychological stress has been suggested to produce a shift in the levels of Th1 and Th2 cytokines towards a Th2 response, a decline in natural killer cell activity, and a decrease in IFNy production, all of which would affect the ability of the immune system to detect and respond to the presence of tumor cells [103]. Holden and colleagues have also suggested a causal immunological model in which a stress-related increase in TNF $\alpha$ results in decreased activity of tyrosine phosphatase and in a consequently diminished expression of the class-I MHC antigen on the surface of malignant cells, allowing transformed cells to escape detection by the immune system [38].

\section{Stress and DNA repair capacity}

Alternatively, psychological stress has been demonstrated to modulate DNA repair capacity and to promote mutagenesis (Table 2). For example, highly distressed psychiatric patients show significantly lower DNA repair capacity following X-ray irradiation then less distressed individuals [104]. Also, in peripheral blood lymphocytes and in spleens from stressed rats, levels of an important
DNA repair enzyme, O6-methylguanine-methyltransferase, are reduced as compared with those obtained from control rats [105]. Interestingly, a study of medical students during examination stress demonstrated an increase in DNA repair capacity during the period of stress, which the authors interpreted as an initial cellular response to an increase in DNA damage [106]. Such promotion of mutagenesis in response to stress has been observed in other studies. Rats exposed to environmental stressors exhibit a marked increase in the rate of sister chromatid exchanges (an event correlated with both mutagenesis and an increase in cancer risk) [107], and are more susceptible to mutagenesis induced by $\gamma$-irradiation and mitomycin-C [108]. Similarly, a higher rate of DNA mutation occurrence due to oxidative damage is found in rats undergoing psychological distress [109].

Some molecular in vitro results have recently become available with regard to the involvement of stress signaling in DNA repair. In murine 3T3 cells, cortisol treatment was found to increase intracellular DNA damage by approximately fivefold and to interfere with the repair of ultraviolet-induced DNA damage [110]. In addition, a gene array experiment demonstrated that cortisol modulates the expression of genes involved in DNA damage signaling, including the proto-oncogene $C d c 25 A$ (involved in cell cycle delay following DNA damage) and the genes coding for the DNA damage sensors Chk1, Rad53 and Rad9 [110].

Our own studies have shown in mouse mammary cell lines that cortisol downregulates the expression of the BRCA1 gene [63]. As an important regulator of both DNA repair and apoptosis, the expression of this gene is critical in the development of breast cancer - demonstrated by its frequent mutation in familial breast cancers $[111,112]$ and its downregulation in many sporadic breast tumors [113]. The loss of $50 \%$ of BRCA1 function in $B R C A 1$ mutation carriers leads to an altered profile of gene expression, which resembles the genetic profile of $B R C A 1$-associated hereditary carcinomas [114]. The approximately $50 \%$ decrease in $B R C A 1$ levels we observed in response to elevated cortisol levels is therefore biologically significant. To date, $B R C A 1$ regulation is the only breast-specific DNA repair pathway that has been linked to cortisol signaling.

\section{Future directions in molecular research}

Many of the molecular systems described need to be tested in the context of mammary gland biology in order to validate their specific contribution to breast cancer development in response to stress. Another future direction in this field should be the application of molecular tools to other scientific disciplines studying stress and breast cancer. This expansion would allow for a demonstration of the biological significance of different types of 


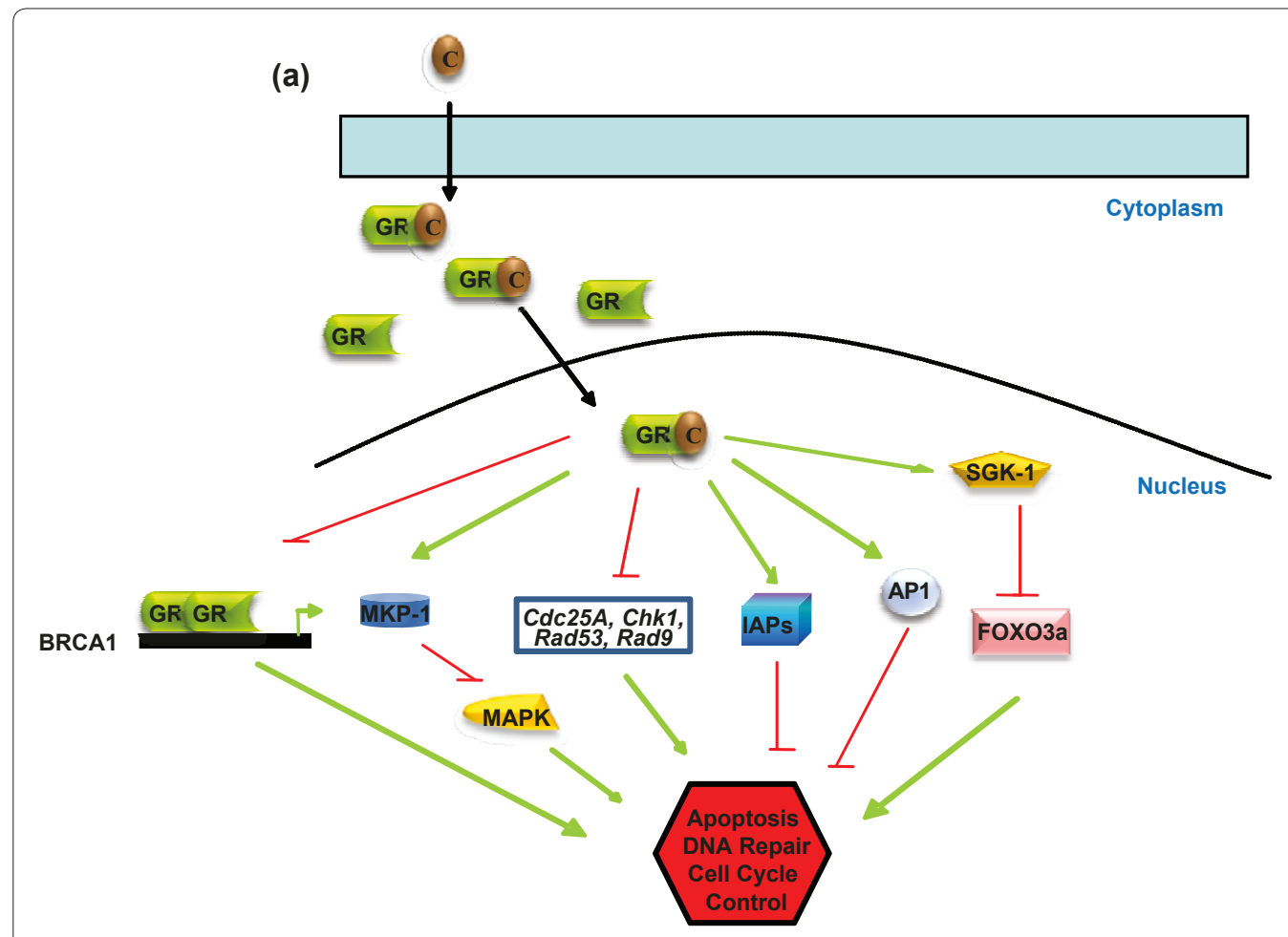

(b)

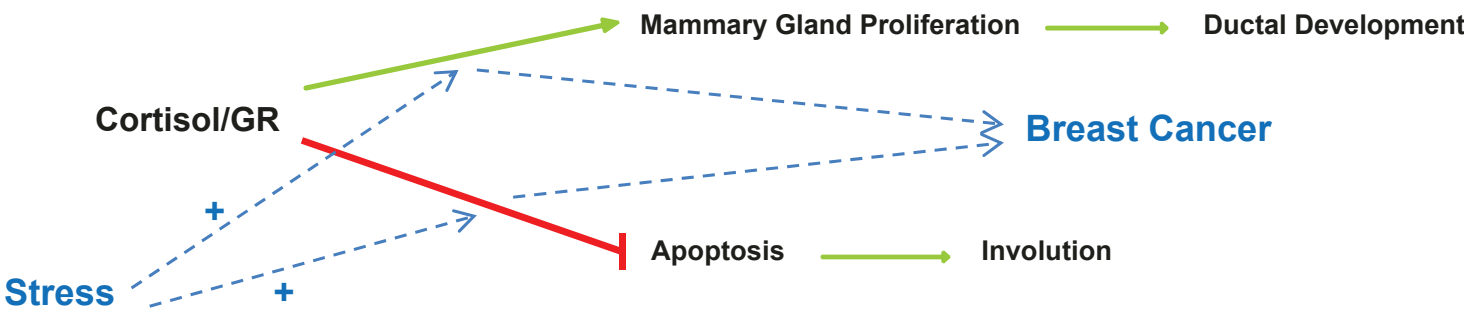

Figure 2. Mechanisms of stress signaling in breast cells and of stress-induced breast cancer development. (a) Mechanisms of stress signaling in breast cells. Stress-induced cortisol (C) binding to the glucocorticoid receptor (GR) causes translocation of the GR to the cell nucleus and changes in the expression of apoptotic and DNA repair genes. Some possible protumorigenic mechanisms include loss of GR transactivation at the breast cancer susceptibility gene 1 (BRCA1) promoter, stimulation of activator protein (AP)-1 transrepressing activities, activation of serum and glucocorticoid-regulated kinase-1 (SGK-1), repression of mitogen-activated protein kinase (MAPK) signaling, suppression of inhibitors of apoptosis protein (IAP) degradation, and modulation of the levels of DNA damage sensor and response proteins. Green arrows represent a positive effect, red lines represent a negative effect. (b) A model of stress-induced breast cancer development. The cortisol-activated GR stimulates mammary gland proliferation during development and represses involution. Prolonged presence of cortisol, such as in periods of stress, leads to an increase in both the proproliferative and antiapoptotic effects of the receptor creating transformation-promoting intracellular conditions. FOXO3a, Forkhead transcription factor 3a; MKP-1, mitogen-activated protein kinase phosphatase-1.

stress exposure (that is, the molecular pathways affected) or for obtaining a quantitative measure of the effect of stress on mammary cells. For example, as previously discussed, the seemingly different epidemiologic effects of work strain or life events on breast cancer risk may stem from discordance in the molecular mechanisms involved. This can be tested by looking at changes in relevant gene expression (for example, expression of apoptotic or DNA repair genes) in response to each type of stress. The observed effect of stress timing on breast cancer risk can also be explained by studying the effect of stress on gene expression at different stages of 
development. Alternatively, the effect of stress exposure on known GR targets or changes in GR gene methylation patterns can be used to confirm stress exposure occurrence in both animal and human studies.

\section{Summary and conclusion}

Elucidation of the factors contributing to the incidence of breast cancer is of crucial importance for the development of therapeutic or preventative strategies targeting the disease. Exposure to psychological stress and stressrelated cortisol release have been proposed to be associated with increased breast cancer risk. In the present review we have provided an overview of the current knowledge on stress signaling and breast cancer, incorporating findings from the several disciplines involved (a summary model is presented in Figure 2).

Epidemiologic evidence has been difficult to interpret due to use of different measures of stress and other study methods that lead to inconsistent findings. Recent reviews have helped to pinpoint the areas of strongest association and have demonstrated that findings depend on the type of study design and the method of exposure measurement. These reviews, however, have also demonstrated a need for more well-devised studies - ideally, prospective cohorts that take into account confounding factors and focus on specific types and timing of stress exposure. The large population-based cohorts currently underway are likely to soon generate more definitive answers.

Consolidation of knowledge in the area of physiological research demonstrates that laboratory studies, in the most part, support a stress-breast cancer association. This is consistent with findings from epidemiologic studies looking at the effect of life events on breast cancer risk. Since epidemiologic evidence is strongest for a specific type of stress exposure, a need exists for a variation in the types of stress methods used in physiologic studies.

Molecular work on the effects of stress in breast cells in particular is still in its early stages. Some initial efforts have been applied towards identifying the intracellular pathways affected by cortisol. The suppressive effect of cortisol on the apoptotic ability and DNA repair capacity of cells, as well as its negative effect on immunity, suggests that a connection between stress signaling and tumor development is biologically plausible. Additional research is needed to identify the particular DNA repair and apoptosis genes affected by cortisol and to verify whether pathways affected in other cell types are also targeted by cortisol in breast cells.

The study of stress and mammary gland malignancy may be greatly aided by the employment of an interdisciplinary approach to research in this field. As knowledge of stress signaling in the breast increases, these new findings can be applied to other research areas. For example, assessment of the activity of GR-related genes or binding partners could be included in physiological studies in order to establish a clear path between external stress exposure and intracellular effects, or a combination of physiological measures of stress, such as salivary cortisol levels, with epidemiologic methods could be included to provide a more accurate assessment of stress exposure at various relevant periods of life. There is a need for understanding the differing physiological effects of types or times of stress exposure. This need can be addressed with the use of both physiological methods to measure hormonal effects and molecular methods to identify differences in gene regulation. Finally, the use of molecular measures of stress susceptibility - such as the identification of GR polymorphisms in epidemiologic studies - may help to eliminate a potentially important source of study discrepancy in that field.

\section{Abbreviations}

$B R C A 1$, breast cancer susceptibility gene 1; Cl, confidence interval; GR, glucocorticoid receptor; HPA, hypothalamic-pituitary-adrenal; IFN, interferon; $\mathrm{OR}$, odds ratio; Th, T-helper type cell; TNF, tumor necrosis factor.

\section{Author details}

${ }^{1}$ Center for Cancer Therapeutics, Ottawa Hospital Research Institute, 501 Smyth Rd, TOHCC 3rd floor, Ottawa, ON, K1H 8L6, Canada. ${ }^{2}$ Queen's Cancer Research Institute, Suite 300, 10 Stuart Street, Kingston, ON, K7L 3N6 Canada.

\section{Competing interests}

The authors declare that they have no competing interests.

\section{Published: 21 April 2011}

\section{References}

1. Madigan M, Ziegler R, Benichou J, Byrne C, Hoover R: Proportion of breast cancer cases in the United States explained by well-established risk factors. J Nat/ Cancer Inst 1995, 87:1681-1685.

2. Tonin P: Genes implicated in hereditary breast cancer syndromes. Semin Surg Oncol 2000, 18:281-286.

3. Hankiston S, Colditz G, Willett W: Towards an integrated model for breast cancer etiology. The lifelong interplay of genes, lifestyle, and hormones. Breast Cancer Res 2004, 6:213-218.

4. Gerber B, Muller H, Reimer T, Krause A, Friese K: Nutrition and lifestyle factors on the risk of developing breast cancer. Breast Cancer Res Treat 2003, 79:265-276.

5. Bleiker E, van der Ploeg H: Psychosocial factors in the etiology of breast cancer: review of a popular link. Patient Educ Couns 1999, 37:201-214.

6. Schwarz R, Geyer S: Social and psychological differences between cancer and noncancer patients: cause or consequence of the disease? Psychother Psychosom 1984, 41:195-199.

7. Petticrew M, Fraser J, Regan M: Adverse life-events and risk of breast cancer: a meta-analysis. Br J Health Psychol 1999, 4:1-17.

8. Duijts S, Zeegers M, Vd Borne B: The association between stressful life events and breast cancer risk: a meta-analysis. Int J Cancer 2003, 107:1023-1029.

9. Nielsen N, Gronbaek M: Stress and breast cancer: a systemic update on the current knowledge. Nat Clin Pract Oncol 2006, 3:612-620.

10. Michael Y, Carlson N, Chlebowski R, Aickin M, Weihs K, Ockene J, Bowen D, Ritenbaugh C: Influence of stressors on breast cancer incidence in the Women's Health Initiative. Health Psychol 2009, 28:137-146.

11. Helgesson O, Cabrera C, Lapidus L, Bengtsson C, Lissner L: Self-reported stress levels predict subsequent breast cancer in a cohort of Swedish women. Eur J Cancer Prev 2003, 12:377-381.

12. Matthews K, Gallo L, Taylor S: Are psychosocial factors mediators of 
socioeconomic status and health connections? Ann NY Acad Sci 2010, 1186:146-173.

13. Chida Y, Hamer M: Chronic psychosocial factors and actute physiological responses to laboratory-induced stress in healthy populations: a quantitative review of 30 years of investigations. Psychol Bull 2008, 134:829-885.

14. Chrousos G: Stress and disorders of the stress system. Nat Rev Endocrin 2009, 5:374-381

15. Kuper $H$, Yang $L$, Theorell T, Weiderpass E: Job strain and risk of breast cancer. Epidemiology 2007, 18:764-768.

16. Nielsen N, Stahlberg C, Strandberg-Larsen K, Kristensen T, Zhang Z, Hundrup Y, Gronbaek M: Are work-related stressors associated with diagnosis of more advanced stages of incident breast cancers? Cancer Causes Control 2008, 19:297-303.

17. Schernhammer E, Hankinson S, Rosner B, Kroenke C, Willett W, Colditz G, Kawachi I: Job stress and breast cancer risk: the Nurses' Health Study. Am J Epidemiol 2004, 160:1079-1086

18. Kroenke C, Hankinson S, Schernhammer E, Colditz G, Kawachi I, Holmes M: Caregiving stress, endogenous sex steroid hormone levels, and breast cancer incidence. Am J Epidemio/ 2004, 159:1019-1027.

19. Nielsen N, Zhang Z, Kristensen T, Netterstrom B, Schnohr P, Gronbaek M: Self reported stress and risk of breast cancer: prospective cohort study. BrMed J 2005, 331:548-550

20. Surtees P, Wainwright N, Luben R, Khaw K, Bingham S: No evidence that social stress is associated with breast cancer incidence. Breast Cancer Res Treat 2010, 120:169-174.

21. Metcalfe C, Davey Smith G, Macleod J, Hart C: The role of self-reported stress in the development of breast cancer and prostate cancer: a prospective cohort study of employed males and females with 30 years of follow-up. Eur J Cancer 2007, 43:1060-1065

22. Lillberg K, Verkasalo P, Kaprio J, Teppo L, Helenius H, Koskenvuo M. Stressful life events and risk of breast cancer in 10,808 women: a cohort study. Am J Epidemio/ 2002, 157:415-423.

23. Lambe M, Cerrato R, Askling J, Hsieh C: Maternal breast cancer risk after death of a child. Int J Cancer 2004, 110:763-766.

24. Ollonen P, Lehtonen J, Eskelinen M: Stressful and adverse life experiences in patients with breast symptoms; a prospective case-control study in Kuopio, Finland. Anticancer Res 2005, 25:531-536.

25. Land C, Tokunaga M, Koyama K, Soda M, Preston D, Nishimori I, Tokuoka S Incidence of female breast cancer among atomic bomb survivors, Hiroshima and Nagasaki, 1950-1990. Radiat Res 2003, 160:707-717.

26. Tokunaga M, Norman JJ, Asano M, Tokuoka S, Ezaki H, Nishimori I, Tsuji Y: Malignant breast tumors among atomic bomb survivors, Hiroshima and Nagasaki, 1950-74. J Nat/ Cancer Inst 1979, 62:1347-1359.

27. Lillberg K, Verkasalo PK, Kaprio J, Teppo L, Helenius H, Koskenvuo M: Stressful life events and risk of breast cancer in 10,808 women: a cohort study. Am J Epidemio/ 2003, 157:415-423.

28. Eskelinen M, Ollonen P: Life stress due to losses and deficit in childhood and adolescence as breast cancer risk factor: a prospective case-control study in Kuopio, Finland. Anticancer Res 2010, 30:4303-4308.

29. Jacobs J, Bovasso G: Early and chronic stress and their relation to breast cancer. Psychol Med 2000, 30:669-678

30. Keinan-Boker L, Vin-Raviv N, Liphshitz I, Linn S, Barchana M: Cancer incidence in Israeli Jewish survivors of World War II. J Natl Cancer Inst 2009, 101:1489-1500.

31. Koupil I, Plavinskaja S, Parfenova N, Shestov D, Danziger P, Vågerö D: Cancer mortality in women and men who survived the siege of Leningrad (19411944). Int I Cancer 2009 , 124:1416-1421.

32. Mason J: A historical view of the stress field. J Hum Stress 1975, 1:6-12 contd.

33. Selye H: Confusion and controversy in the stress field. J Hum Stress 1975 $1: 37-44$

34. Harbuz M, Lightman S: Stress and the hypothalamo-pituitary-adrenal axis: acute, chronic and immunological activation. J Endocrino/ 1992, 134:327-339.

35. Keller S, Weiss J, S. S, Miller N, Stein M: Stress-induced suppression of immunity in adrenalectomized rats. Science 1983, 221:1301-1304.

36. Homo-Delarche F, Fitzpatrick F, Christeff N, Nunez E, Bach J, Dardenne M: Sex steroids, glucocorticoids, stress and autoimmunity. J Steroid Biochem Mol Biol 1991, 40:619-637.

37. Vanltallie T. Stress: a risk factor for serious illness. Metabolism 2002, 51:40-45.
38. Holden R, Pakula I, Mooney P: An immunological model connecting the pathogenesis of stress, depression and carcinoma. Med Hypotheses 1998, 51:309-314.

39. Strange K, Kerr L, Andrews H, Emerman J, Weiberg J: Psychosocial stressors and mammary tumour growth: an animal model. Neurotoxicol Teratol 2000 22:89-102.

40. Hennighausen L, Robinson G: Signaling pathways in mammary gland development. Dev Cell 2001, 1:467-475.

41. Robinson G, Smith G, Gallahan D, Zimmerm A, Furth P, Hennighausen L: Understanding mammary gland development through the imbalanced expression of growth regulators. Dev Dyn 1996, 206:159-168.

42. Gilbert S: Developmental Biology. 8th edition. Sunderland, MA: Sinauer Associates; 2006

43. Majumder $\mathrm{P}$, Joshi J, Banerjee M: Correlation between nuclear glucocorticoid receptor levels and casein gene expression in murine mammary gland in vitro. J Bio/ Chem 1983, 258:6793-6798.

44. Reichardt H, Horsch K, Grone H, Kolbus A, Beug H, Hynes N, Schutz G: Mammary gland development and lactation are controlled by different glucocorticoid receptor activities. Eur J Endocrino/ 2001, 145:519-527.

45. Wintermantel T, Bock D, Fleig V Greiner E, Schutz G. The epithelial glucocorticoid receptor is required for the normal timing of cell proliferation during mammary lobuloalveolar development but is dispensable for milk production. Mol Endocrinol 2005, 19:340-349.

46. Maina G, Bovenzi M, Palmas A, Larese Filon F: Associations between two job stress models and measures of salivary cortisol. Int Arch Occup Environ Health 2009, 82:1141-1150.

47. Chida Y, Steptoe A: Cortisol awakening response and psychosocial factors: a systematic review and meta-analysis. Biol Psychol 2009, 80:265-278.

48. Gonzalez A, Jenkins J, Steiner M, Fleming A: The relation between early life adversity, cortisol awakening response and diurnal salivary cortisol levels in postpartum women. Psychoneuroendocrinology 2009, 34:76-86.

49. Elzinga B, Roelofs K, Tollenaar M, Bakvis P, van Pelt J, Spinhoven P: Diminished cortisol responses to psychosocial stress associated with lifetime adverse events: a study among healthy young subjects. Psychoneuroendocrinology 2008, 33:227-237.

50. Heim C, Newport D, Wagner D, Wilcox M, Miller A, Nemeroff C: The role of early adverse experience and adulthood stress in the prediction of neuroendocrine stress reactivity in women: a multiple regression analysis. Depress Anxiety 2002, 15:117-125

51. Henderson B, Ross R, Bernstein L: Estrogens as a cause of human cancer: the Richard and Hinda Rosenthal Foundation award lecture. Cancer Res 1988, 48:246-253.

52. Russo J, Hasan Lareef M, Balogh G, Guo S, Russo I: Estrogen and its metabolites are carcinogenic agents in human breast epithelial cells. J Steroid Biochem Mol Biol 2003, 87:1-25.

53. Simpson E: Sources of estrogen and their importance. J Steroid Biochem Mol Biol 2003, 86:225-230.

54. Simpson E: Biology of aromatase in the mammary gland. J Mammary Gland Biol Neoplasia 2000, 5:251-258.

55. O'Neill J, Elton R, Miller W: Aromatase activity in adipose tissue from breast quadrants: a link with tumour site. BrMed J 1988, 296:741-743.

56. Bulun S, Price T, Aitken J, Mahendroo M, Simpson E: A link between breast cancer and local estrogen biosynthesis suggested by quantification of breast adipose tissue aromatase cytochrome P450 transcripts using competitive polymerase chain reaction after reverse transcription. J Clin Endocrinol Metab 1993, 77:1622-1628.

57. Brodie A, Lu Q, Nakamura J: Aromatase in the normal breast and breast cancer. ISteroid Biochem Mol Biol 1997, 61:281-286.

58. Simpson E, Ackerman G, Smith M, Mendelson C: Estrogen formation in stromal cells of adipose tissue of women: induction by glucocorticosteroids. Proc Natl Acad Sci U S A 1981, 78:5690-5694

59. Schmidt M, Loffler G. Induction of aromatase in stromal vascular cells from human breast adipose tissue depends on cortisol and growth factors. FEBS Lett 1994, 341:177-181.

60. Schmidt M, Loffler G: RU486 is a potent inhibitor of aromatase induction in human breast adipose tissue stromal cells. J Steroid Biochem Mol Biol 1997, $60: 197-204$

61. Romagnolo D, Annab L, Thompson T, Risinger J, Terry L, Barrett J, Afshari C: Estrogen upregulation of BRCA1 expression with no effect on localization. Mol Carcinog 1998, 22:102-109.

62. Razandi M, Pedram A, Rosen E, Levin E: BRCA1 inhibits membrane estrogen 
and growth factor receptor signaling to cell proliferation in breast cancer Mol Cell Biol 2004, 24:5900-5913.

63. Antonova L, Mueller $\mathrm{C}$ : Hydrocortisone down-regulates the tumor suppressor gene BRCA1 in mammary cells: a possible molecular link between stress and breast cancer. Genes, Chromosomes Cancer 2008 47:341-352.

64. Huizenga N, Koper J, de Lange P, Pols H, Stolk R, Burger H, Grobbee D, Brinkmann A, de Jong F, Lamberts S: A polymorphism in the glucocoritcoid receptor gene may be associated with an increased sensitivity to glucocorticoids in vivo. J Clin Endocrinol Metab 1998, 83:144-151.

65. Di Blasio A, van Rossum E, Maestrini S, Berselli M, Tagliaferri M, Podesta F, Koper J, Liuzzi A, Lamberts S: The relation between two polymorphisms in the glucocorticoid receptor gene and body mass index, blood pressure and cholesterol in obese patients. Clin Endocrinol 2003, 59:68-74.

66. Lin R, Wang W, Morris B: High penetrance, overweight, and glucocorticoid receptor variant: case-control study. Br Med J 1999, 319:1337-1338.

67. Lin R, Wang W, Morris B: Association of coronary artery disease with glucocorticoid receptor N363S variant. Hypertension 2003, 41:404-407.

68. Lin R, Wang W, Dalziel B, Caterson I, Morris B: Association of obesity, but not diabetes or hypertension, with glucocorticoid receptor N363S variant. Obes Res 2003, 11:802-808.

69. Curran J, Lea R, Rutherford S, Weinstein S, Griffiths L: Association of estrogen receptor and glucocorticoid receptor gene polymorphisms with sporadic breast cancer. Int J Cancer (PredOncol) 2001, 95:271-275.

70. Grippo A, Gerena D, Huang J, Kumar N, Shah M, Ughreja R, Sue Carter C: Social isolation induces behavioral and neuroendocrine disturbances relevant to depression in female and male prairie voles. Psychoneuroendocrinology 2007, 32:966-980.

71. Dechambre R, Gosse C: Individual versus group caging of mice with grafted tumors. Cancer Res 1973, 33:140-144.

72. Sklar L, Anisman H: Social stress influences tumor growth. Psychosom Med 1980, 42:347-365.

73. Weinberg J, Emerman J: Effects of psychosocial stressors on mouse mammary tumor growth. Brain Behav Immun 1989, 3:234-246.

74. Grimm M, Emerman J, Weinberg J: Effects of social housing condition and behavior on growth of the Shionogi mouse mammary carcinoma. Physiol Behav 1996, 59:633-642.

75. Hermes G, Delgado B, Tretiakova M, Cavigelli S, Krausz T, Conzen S, McClintock M: Social isolation dysregulates endocrine and behavioral stress while increasing malignant burden of spontaneous mammary tumors. Proc Natl Acad Sci U S A 2009, 106:22393-22398.

76. Williams B, Pang D, Delgado B, Kocherginsky M, Tretiakova M, Krausz T, Pan D, $\mathrm{He}$ J, McClintock M, Conzen S: A model of gene-environment interaction reveals altered mammary gland gene expression and increased tumor growth following social isolation. Cancer Prev Res 2009, 2:850-861.

77. Rao U, Hammen C, Ortiz L, Chen L, Poland R: Effects of early and recent adverse experiences on adrenal response to psychosocial stress in depressed adolescents. Biol Psychiatry 2008, 64:521-526.

78. Faravelli C, Amedei S, Rotella F, Faravelli L, Palla A, Consoli G, Ricca V, Batini S, Sauro C, Spiti A, Dell'osso M: Childhood trauma, dexamethasone suppression test and psychiatric symptoms: a trans-diagnostic approach. Psychol Med 2010, 40:2037-2048.

79. Gerritsen L, Geerlings M, Beekman A, Deeg D, Penninx B, Comijs H: Early and late life events and salivary cortisol in older persons. Psycho/ Med 2010, 40:1569-1578

80. Uchida S, Hara K, Kobayashi A, Funato H, Hobara T, Otsuki K, Yamagata H, McEwen B, Watanabe Y: Early life stress enhances behavioral vulnerability to stress through the activation of REST4-mediated gene transcription in the medial prefrontal cortex of rodents. J Neurosci 2010, 30:15007-15018.

81. Enthoven L, de Kloet $\mathrm{E}$, Oitzl M: Differential development of stress system (re)activity at weaning dependent on time of disruption of maternal care. Brain Res 2008, 1217:62-69.

82. Weaver I, Cervoni N, Champagne F, D'Alessio A, Sharma S, Seckl J, Dymov S, Szyf M, Meaney M: Epigenetic programming by maternal behavior. Nat Neurosci 2004, 7:847-854

83. Liu D, Diorio J, Tannenbaum B, Caldji C, Francis D, Freedman A, Sharma S, Pearson D, Plotsky P, Meaney M: Maternal care, hippocampal glucocorticoid receptors, and hypothalamic-pituitary-adrenal responses to stress. Science 1997, 277:1659-1662.

84. Maina G, Palmas A, Bovenzi M, Larese Filonm F: Salivary cortisol and psychosocial hazards at work. Am J Ind Med 2009, 52:251-260.
85. Borders A, Grobman W, Amsden L, McDade T, Sharp L, Holl J: The relationship between self-report and biomarkers of stress in low-income reproductiveage women. Am J Obstetr Gynecol 2010, 203:1-8.

86. Glaser R, Pearson G, Jones J, Hillhouse J, Kennedy S, Mao H, Kiecolt-Glaser J: Stress-related activation of Epstein-Barr virus. Brain Behav Immun 1991, 5:219-232.

87. Palanza P: Animal models of anxiety and depression: how are females different? Neurosci Biobehav Rev 2001, 25:219-233.

88. Hasen N, O'Leary K, Auger A, Schuler L: Social isolation reduces mammary development, tumor incidence, and expression of epigenetic regulators in wild-type and p53-heterozygotic mice. Cancer Prev Res 2010, 3:620-629.

89. Amsterdam A, Tajima K, Sasson R: Cell-specific regulation of apoptosis by glucocorticoids. Biochem Pharmacol 2002, 64:843-850.

90. Feng Z, Marti A, Jehn B, Altermatt H, Chicaiza G, Jaggi R: Glucocorticoid and progesterone inhibit involution and programmed cell death in the mouse mammary gland. J Cell Biol 1995, 131:1095-1103.

91. Moran T, Gray S, Mikosz C, Conzen S: The glucocorticoid receptor mediates a survival signal in human mammary epithelial cells. Cancer Res 2000, 60:867-872.

92. Wu W, Pew T, Zou M, Pang D, Conzen S: Glucocorticoid receptor-induced MAPK phosphatase-1 (MPK-1) expression inhibits paclitaxel-associated MAPK activation and contributes to breast cancer cell survival. J Biol Chem 2005, 280:4117-4124.

93. Filderman A, Bruckner A, Kacinski B, Deng N, Remold H: Macrophage colonystimulating factor (CSF-1) enhances invasiveness in CSF-1 receptorpositive carcinoma cell lines. Cancer Res 1992, 52:3661-3666.

94. Tangir J, Bonafe N, Gilmore-Hebert M, Henegariu O: SGK1, a potential regulator of $\mathrm{c}-\mathrm{fm}$ related breast cancer aggressiveness. Clin Exp Metastasis 2004, 21:477-483.

95. Lien H, Lu Y, Cheng A, Chang W, Jeng Y, Kuo Y, Huang C, Chang K, Yao Y: Differential expression of glucocorticoid receptor in human breast tissues and related neoplasms. J Pathol 2006, 209:317-327.

96. Lippman M, Bolan G, Huff K: The effects of glucocorticoids and progesterone on hormone-responsive human breast cancer in long-term tissue culture. Cancer Res 1976, 36:4602-4609.

97. Goya L, Maiyar A, Ge Y, Firestone G: Glucocorticoids induce a G1/G0 cell cycle arrest of Con 8 rat mammary tumor cells that is synchronously reversed by steroid withdrawal or addition of transforming growth factoralpha. Mol Endocrinol 1993, 7:1121-1132

98. Rocha Viegas L, Hoijman E, Beato M, Pecci A: Mechanisms involved in tissuespecific apoptosis regulated by glucocorticoids. J Steroid Biochem Mol Biol 2008, 109:273-278

99. Moutsatsou P, Papavassiliou A: The glucocorticoid receptor signalling in breast cancer. J Cell Mol Med 2008, 12:145-163.

100. Wu W, Zou M, Brickley D, Pew T, Conzen S: Glucocorticoid receptor activation signals through Forkhead Transcription Factor 3a in breast cancer cells. Mol Endocrinol 2006, 20:2304-2314.

101. Messmer U, Pereda-Fernandez C, Manderscheid M, Pfeilschifter J: Dexamethasone inhibits TNFa-induced apoptosis and IAP protein downregulation in MCF-7 cells. Br J Pharmacol 2001, 133:467-476.

102. Webster Marketon J, Glaser R: Stress hormones and immune function. Cell Immunol 2008, 252:16-26.

103. Yang E, Glaser R: Stress-induced immunomodulation: implications for tumorigenesis. Brain Behav Immun 2003, 17:S37-S40.

104. Kiecolt-Glaser J, Stephens R, Lipetz P, Speicher C, Glaser R: Distress and DNA repair in human lymphocytes. J Behav Med 1985, 8:311-320.

105. Glaser R, Kiecolt-Glaser J, Stout J, Tarr K, Speicher C, Holliday J: Stress-related impairments in cellular immunity. Psychiatry Res 1985, 16:233-239.

106. Cohen L, Marshall GJ, Cheng L, Sandeep A, Wei Q: DNA repair capacity in healthy medical students during and after exam stress. J Behav Med 2000, 23:531-544.

107. Fischman H, Pero R, Kelly D: Psychogenic stress induces chromosomal and DNA damage. Int J Neurosci 1996, 84:219-227.

108. Sacharczuk M, Jaszczak K, Sadowski B: Cytogenetic comparison of the sensitivity to mutagens in mice selected for high (HA) and low (LA) swim stress-induced analgesia. Mutat Res/Genet Toxicol Environ Mutagen 2003, 535:95-102.

109. Adachi S, Kawamura K, Takemoto K: Oxidative damage of nuclear DNA in liver of rats exposed to psychological stress. Cancer Res 1993, 53:4153-4155.

110. Flint M, Baum A, Chambers W, Jenkins F: Induction of DNA damage, alteration of DNA repair and transcriptional activation by stress hormones. 
Psychoneuroendocrinology 2007, 32:470-479.

111. Miki Y, Swensen J, Shattuck-Eidens D, Futreal P, Harshman K, Tavtigian S, Liu Q, Cochran C, Bennett LM, Ding W, et al:: A strong candidate for the breast and ovarian cancer susceptibility gene BRCA1. Science 1994, 266:66-71.

112. Easton D, Ford D, Bishop D: Breast and ovarian cancer incidence in BRCA1mutation carriers. Breast Cancer Linkage Consortium. Am J Hum Genet 1995, 56:265-271.

113. Thompson M, Jensen R, Obermiller P, Page D, Holt J: Decreased expression of BRCA1 accelerates growth and is often present during sporadic breast cancer progression. Nat Genet 1995, 9:444-450.
114. Bellacosa A, Godwin A, Peri S, Devarajan K, Caretti E, Vanderveer L, Bove B, Slater C, Zhou Y, Daly M, et al: Altered gene expression in morphologically normal epithelial cells from heterozygous carriers of BRCA1 or BRCA2 mutations. Cancer Prev Res 2010, 3:48-61.

doi:10.1186/bcr2836

Cite this article as: Antonova $L$, et al.: Stress and breast cancer: from epidemiology to molecular biology. Breast Cancer Research 2011, 13:208. 